\title{
Selected Constituent Yield Variation in the Smoke of Commercial Cigarette Brands on the Japanese Market *
}

\author{
by \\ Takatsugu Hyodo \\ Japan Tobacco INC, 2-2-1 Toranomon Minato-ku, Tokyo 105-8422, Japan
}

\section{SUMMARY}

This study focused on the variation in the yields of constituents in smoke from commercial cigarette brands available on the Japanese market. Nineteen commercial cigarette brands were sampled five times every two months from 2009 to 2010 . The target constituents were benzo[a]pyrene, 1,3-butadiene, benzene, formaldehyde, acetaldehyde, acrolein, $N$-nitrosonornicotine (NNN), 4(methylnitrosamino)-1-(3-pyridyl)-1-butanone (NNK), carbon monoxide, "tar", and nicotine. The results of this study showed that the coefficient of variation $(\mathrm{CV})$ values varied greatly by brands, constituents, and smoking regimes. The yields of NNN and NNK in the smoke were strongly correlated to their yields in the tobacco filler blend for most brands. The yields of benzo $[a]$ pyrene under the International Organization for Standardization (ISO) and the Health Canada Intense (HCI) smoking regimes and 1,3butadiene under the HCI smoking regime were found to be influenced by the measurement. It was shown that factors for variation were highly varied among constituents. The grand mean of $\mathrm{CV}$ values for $\mathrm{NNN}$ and formaldehyde associated with cigarette manufacturing over ten months and measurement at the JT laboratory under the HCI smoking regimes were $17.1 \%$ and $6.6 \%$ respectively. The grand mean of $\mathrm{CV}$ values for $\mathrm{NNN}$ and formaldehyde associated with both cigarette manufacturing over ten months and measurement at different laboratories under the HCI smoking regimes were $23.7 \%$ and $22.9 \%$ respectively. This is due to the fact that formaldehyde showed the highest CV values for reproducibility among the constituents. Thus, in order to set realistic and robust confidence intervals, it is very important to take into account the variations associated with cigarette manufacturing and measurement within and between laboratories. [Beitr. Tabakforsch. Int. 27 (2017) 208-223]

\section{ZUSAMMENFASSUNG}

Diese Studie untersucht die Variation bei den Ausbeuten von Rauchbestandteilen von Zigaretten, die auf dem japanische Markt im Handel erhältlich sind. Neunzehn im Handel erhältliche Zigarettenmarken wurden zwischen 2009 und 2010 fünf Mal jeweils im Abstand von zwei Monaten beprobt. Die untersuchten Bestandteile waren Benzo[a]pyren, 1,3-Butadien, Benzol, Formaldehyd, Acetaldehyd, Acrolein, $N$-Nitrosonornikotin (NNN), 4(Methylnitros-amino)-1-(3-pyridyl)-1-butanon (NNK), Kohlenmonoxid, "Teer" und Nikotin. Die Ergebnisse dieser Studie zeigten, dass die Variationskoeffizienten (VK) je nach Marke, Bestandteilen und Rauchprotokoll stark variierten. Der Gehalt von NNN und NNK im Rauch korreliert für die meisten Marken stark mit dem jeweiligen Gehalt in der Tabakfüllstoffmischung. Es wurde festgestellt, dass die Ausbeuten von Benzo[ $[a]$ pyren nach den Rauchprotokollen der International Organization for Standardization (ISO) und Health Canada Intense (HCI) und von 1,3-Butadien nach dem HCI-Rauchprotokoll von der Messung beeinflusst waren. Es wurde gezeigt, dass die Faktoren für Variation unter den Bestandteilen stark variierten. Der Gesamtmittelwert von VK-Werten für NNN und Formaldehyd, der mit der Zigarettenherstellung über zehn Monate und der Messung im JT Labor nach den HCIRauchprotokollen assoziiert ist, betrug jeweils $17.1 \%$ und $6.6 \%$. Der Gesamtmittelwert von VK-Werten für NNN und Formaldehyd, der sowohl mit der Zigarettenherstellung über zehn Monate als auch mit der Messung in verschiedenen Laboren nach den HCI-Rauchprotokollen assoziiert ist, betrug jeweils $23.7 \%$ und $22.9 \%$. Der Grund dafür ist, dass Formaldehyd unter den Bestandteilen die höchsten $\mathrm{KV}$-Werte für die Reproduzierbarkeit aufwies. Um demnach realistische und solide Konfidenzintervalle festzulegen, muss unbedingt die Variation berücksichtigt werden, 
die mit der Zigarettenherstellung und der Messung innerhalb von und zwischen Laboren assoziiert ist. [Beitr. Tabakforsch. Int. 27 (2017) 208-223]

\section{RESUME}

La présente étude s'attarde sur la variation des rendements des composants de la fumée émise par les cigarettes dont la marque est commercialisée sur le marché japonais. Cinq fois tous les deux mois entre 2009 et 2010, des échantillons furent prélevés sur des cigarettes commercialisées sous dix-neuf marques. Les composants visés étaient le benzo[a]pyrène, le 1,3-butadiène, le benzène, le formaldéhyde, l'acétaldéhyde, l'acroléine, la $N$-nitrosonornicotine $(\mathrm{NNN})$, la 4(méthylnitrosamino)-1-(3-pyridyle)-1-butanone (NNK), le monoxyde de carbone, le "goudron" et la nicotine. Les résultats de la présente étude démontrent que les valeurs du coefficient de variation (CV) varient grandement selon les marques, les composants et les paramètres de fumage. Les rendements de la NNN et de la NNK dans la fumée furent fortement corrélés à leurs rendements dans le mélange de tabac haché pour la plupart des marques. Les rendements du benzo $[a]$ pyrène selon les paramètres de fumage de l'Organisation internationale de Normalisation (ISO) et de Santé Canada Intense (HCI) et ceux du 1,3-butadiène selon les paramètres de fumage de HCI s'avérèrent être influencés par le mesurage. Il fut démontré que les facteurs de variation variaient grandement parmi les composants. La moyenne générale des valeurs du CV pour la NNN et le formaldéhyde associées à la fabrication de cigarettes sur 10 mois et au mesurage réalisé par le laboratoire JT selon les paramètres de fumage de HCI fut respectivement de $17.1 \%$ et $6.6 \%$. La moyenne générale des valeurs de $\mathrm{CV}$ pour la $\mathrm{NNN}$ et le formaldéhyde associées tant à la fabrication de cigarettes sur 10 mois qu'au mesurage réalisé par différents laboratoires selon les paramètres de fumage de $\mathrm{HCI}$ fut respectivement de $23.7 \%$ et $22.9 \%$. Ces écarts s'expliquent par le fait que le formaldéhyde présente, parmi les composants, les valeurs de CV les plus élevées pour la reproductibilité. Par conséquent, afin de déterminer des intervalles de confiance réalistes et solides, il est essentiel de tenir compte de la variation associée à la fabrication de la cigarette et au mesurage au sein d'un même laboratoire et entre les laboratoires. [Beitr. Tabakforsch. Int. 27 (2017) 208-223]

\section{INTRODUCTION}

The regulatory pressure on tobacco products is beeing reinforced globally. The constituents of cigarette smoke, other than "tar" and nicotine, have received increasing attention in recent years. The World Health Organization (WHO) Study Group on Tobacco Product Regulation has recommended benzo[a]pyrene, 1,3-butadiene, benzene, formaldehyde, acetaldehyde, acrolein, $N$-nitrosonornicotine (NNN), 4-(methylnitrosamino)-1-(3-pyridyl)-1-butanone (NNK), and carbon monoxide as the priority constituents in cigarette smoke that need to be reduced (1). Cooperation Centre for Scientific Research Relative to Tobacco (CORESTA) Recommended Methods (CRMs) provide analytical methods for yields of these constituents, including their repeatability and reproducibility (2-5). In addition, the CRMs have been further developed at the International Organization for Standardization (ISO).

There are not a great number of studies on the variation in the yields of constituents in smoke within a given commercial cigarette brand over time (6-13). The important point from these studies was that the variation in the yields of smoke constituents is associated with cigarette manufacturing and measurement, and that they cannot be calculated separately. The variation associated with cigarette manufacturing, out of the total variability, was evaluated by comparing the coefficient of variation $(\mathrm{CV})$ values of monitor cigarettes and commercial cigarette brands $(7,8)$. The measurement variation in the yields of 1,3-butadiene in smoke was highlighted since similar trends were observed in commercial cigarette brands and monitor cigarettes (7). PIADÉ et al. summarized the precursors and possible selective filtration of smoke constituents that were targeted in this study (14). The factors affecting the variation in the yields of NNN and NNK in smoke have been reported and explained by their yields present in the tobacco filler blend (7, 9, and 12).

Studies on variation in the yields of smoke constituents other than NNN and NNK have not been published with commercial cigarette brands available on the Japanese market. Many cigarette brands on the Japanese market use charcoal filters. The effect of charcoal filtration on carbonyl reduction in mainstream cigarette smoke was reported (15). The study used filters of commercial cigarette brands which were modified to contain three to four different levels of charcoal in filters. However, there are no studies that report the influence of the amount variation of charcoal in the filter on the yields of the constituents in the vapor phase within a given brand.

The cigarette itself and the laboratory measurement are two major sources of statistical variation. Both of these sources result in fluctuations over short and long term. Measurements may also vary between laboratories, even for matched cigarette samples. In the context of package labeling, the yields of "tar", nicotine, and carbon monoxide are determined from laboratory tests carried out by the manufacturer on cigarettes sampled from production. Checks by a designated laboratory occur later, after the manufacturer has determined and printed its values on the cigarette package (16). ISO 8243 provides the estimated typical confidence intervals in the yields of "tar", nicotine, and carbon monoxide (16). These confidence intervals are represented by repeatability and reproducibility calculated from matched cigarette samples (17). Currently, the confidence intervals have not been set for constituents other than "tar", nicotine, and carbon monoxide under the ISO smoking regime. In addition, no studies have reported variation over time that accounts for both cigarette manufacturing and measurement between laboratories. CORESTA Cigarette Variability Task Force has been conducting a long term collaborative study since 2015 to improve the understanding of overall tobacco and smoke constituent variability relevant to commercial cigarette design features.

This study aimed to understand variations associated with cigarette manufacturing and measurements within a laboratory over time on the selected constituent yields in 
Table 1. Cigarette brand specifications. Brand No. 20 was used for evaluating measurement variation during this study.

\begin{tabular}{|c|c|c|c|c|c|c|}
\hline No. & $\begin{array}{c}\text { Labeled "tar" } \\
\text { (mg/cig) }\end{array}$ & $\begin{array}{c}\text { Labeled nicotine } \\
(\mathrm{mg} / \mathrm{cig})\end{array}$ & $\begin{array}{c}\text { Length }^{a} \\
(\mathrm{~mm})\end{array}$ & $\begin{array}{c}\text { Circumference }{ }^{\mathrm{b}} \\
(\mathrm{mm})\end{array}$ & Filter type ${ }^{c}$ & Manufacturer \\
\hline 1 & 1 & 0.1 & regular & regular & $A C$ & $\mathrm{JT}$ \\
\hline 2 & 1 & 0.1 & regular & regular & $A C$ & non-JT \\
\hline 3 & 1 & 0.1 & regular & regular & $A C$ & non-JT \\
\hline 4 & 1 & 0.1 & long & slim & A & $\mathrm{JT}$ \\
\hline 5 & 1 & 0.1 & long & regular & $A C$ & JT \\
\hline 6 & 3 & 0.3 & regular & regular & $A C$ & JT \\
\hline 7 & 3 & 0.3 & regular & regular & $A C$ & non-JT \\
\hline 8 & 3 & 03 & regular & regular & $A C$ & non-JT \\
\hline 9 & 3 & 0.2 & long & slim & A & $\mathrm{JT}$ \\
\hline 10 & 3 & 0.3 & long & regular & $A C$ & JT \\
\hline 11 & 6 & 0.5 & regular & regular & $A C$ & $\mathrm{JT}$ \\
\hline 12 & 6 & 0.5 & regular & regular & $A C$ & non-JT \\
\hline 13 & 6 & 0.5 & regular & regular & $A C$ & non-JT \\
\hline 14 & 5 & 0.3 & long & slim & $A$ & JT \\
\hline 15 & 6 & 0.5 & long & regular & $A C$ & JT \\
\hline 16 & 6 & 0.5 & regular & regular & $A C$ & non-JT \\
\hline 17 & 10 & 0.8 & regular & regular & $A C$ & $\mathrm{JT}$ \\
\hline 18 & 12 & 1.0 & regular & regular & $A C$ & non-JT \\
\hline 19 & 14 & 1.2 & regular & regular & $A C$ & JT \\
\hline 20 & 6 & 0.5 & regular & regular & $A$ & JT \\
\hline
\end{tabular}

${ }^{\text {a }}$ Cigarette length: regular $=83-85 \mathrm{~mm}$, long $=97-100 \mathrm{~mm}$

${ }^{b}$ Cigarette circumference: regular $=24-26 \mathrm{~mm}$, slim $=22-23 \mathrm{~mm}$

${ }^{c}$ Filter type: $A C=$ acetate charcoal filter, $A=$ acetate filter

the mainstream smoke of cigarette brands available on the Japanese market. This study investigated factors influencing the variations such as the measurement of the constituents, the yields of the constituents in the tobacco filler blend, and the yield of charcoal in filter. In addition, this study also aimed to explain the variation associated with cigarette manufacturing and measurement between laboratories based on data from this study and CRMs that describe variation between laboratories.

\section{EXPERIMENTAL}

\section{Cigarette brands}

Nineteen commercial cigarette brands from the Japanese market were selected based on labeled yield of "tar", cigarette length, and cigarette circumference. One commercial brand (No. 20) was selected for evaluating measurement variation during this study period. They are summarized in Table 1. Ten out of the nineteen brands have labeled yields of "tar" of $3 \mathrm{mg} / \mathrm{cig}$ or less. In addition, sixteen brands use a charcoal filter, one of the main features of cigarette brands in the Japanese market.

\section{Sampling}

Seven to ten cartons were collected from the same factory for Japan Tobacco (JT) group brands, and the same warehouse for non-JT group brands, five times every two months from 2009 to 2010 . A single manufacturing lot was used for all testing of each sampling. All five batches were confirmed to be from different batches because batch codes on the cartons were different for the five samplings. There were no changes in the labeled yield of "tar" and nicotine for each brand during the study period. Brand No. 20 was collected at the first sampling and refrigerated at $4{ }^{\circ} \mathrm{C}$. This brand was measured at the same time the nineteen brands were measured every two months.

\section{Analytical methods}

All constituents and design parameters were measured at JT laboratories. Test cigarettes were conditioned at $22{ }^{\circ} \mathrm{C}$ and $60 \%$ relative humidity (18). Filter ventilation, draw resistance, circumference, cigarette weight, and tobacco weight were measured as basic physical properties. The charcoal amount in the filter was weighed after soaking the filter in acetone, separation into filter tow and charcoal, and drying. The target constituents in mainstream smoke were benzo[a]pyrene, 1,3-butadiene, benzene, formaldehyde, acetaldehyde, acrolein, NNN, NNK, "tar", nicotine, and carbon monoxide. "Tar", nicotine, and carbon monoxide yields were analyzed based on the relevant ISO standards (19-23). The total particulate matter (TPM) was calculated from the difference in weight of glass fiber filters (Cambridge filters) used for smoke collection before and after machine smoking. Nicotine and water yields were analyzed by gas chromatography after extraction from the Cambridge filters with 2-propanol. The yield of "tar" was calculated by subtracting the yields of nicotine and water from the TPM yield. Carbon monoxide was analyzed using a non-dispersive infrared analyzer. Benzo $[a]$ pyrene was extracted from the Cambridge filters with cyclohexane, concentrated, then the yield was determined by high performance liquid chromatography with fluorescence detection (HPLC-FLD) 
(24). 1,3-Butadiene and benzene were collected by passing mainstream smoke through Cambridge filters into cooled methanol in impingers, then the yield was determined using gas chromatography with mass spectrometry. Deuterated toluene was used as an internal standard in this study, although deuterated benzene was used in CRM70 (3). Formaldehyde, acetaldehyde, and acrolein were trapped as 2,4-dinitrophenylhydrazine derivatives and their yields were determined using high performance liquid chromatography with diode array detection (4). NNN and NNK were extracted from Cambridge filters used for smoke collection with an ammonium acetate solution, and their yields were determined by liquid chromatography with tandem mass spectrometry (5). Smoking was performed under ISO and Health Canada Intense (HCI) regimes. Puff volume, puff duration, and puff interval for the ISO smoking regime were $35 \mathrm{~mL}, 2 \mathrm{sec}$, and $60 \mathrm{sec}$, respectively (19). Puff volume, puff duration, and puff interval for the HCI smoking regime were $55 \mathrm{~mL}, 2 \mathrm{sec}$, and $30 \mathrm{sec}$, respectively, and filter ventilation holes were $100 \%$ blocked (25). Target constituents in tobacco filler blend were nicotine, NNN, NNK, and total reducing sugars. Nicotine yields were analyzed based on CRM62 (26). n-Hexane was used as a solvent. NNN and NNK were extracted from ground tobacco filler blend using an ammonium acetate solution and their yields were determined by liquid chromatography with tandem mass spectrometry (27). The level of reducing sugars was determined using a continuous flow analyzer by monitoring the decrease in color caused by reduction of yellow hexacyanoferrate(III) to colorless hexacyanoferrate(II) as measured at $420 \mathrm{~nm}$. The smoke constituent measurement was replicated three to four times. Measurement of the nicotine, $\mathrm{NNN}$, NNK, and total reducing sugars in tobacco filler blend were replicated twice.

\section{Data analysis}

Mean, standard deviation, and CV of the constituents in smoke and tobacco filler blend and cigarette design parameters were calculated with five averaged data points from each sampling. Pearson's correlation coefficients were calculated using five averaged data points from each sampling to understand the degree of linear relationships between two parameters. Coefficient of determination is the percentage of the response variable variation that is explained by a linear model. When the value of Pearson's correlation coefficient is 0.7 , then, the value of coefficient of determination is 0.49 , almost 0.5 . Pearson's correlation coefficient of 0.7 , which a parameter explains about $50 \%$ of the variation of constituent yields, was used in this study. Variance associated with cigarette manufacturing over the ten months in this study and repeatability variance from CRMs was combined to understand the variation associated with cigarette manufacturing and measurement between laboratories. Reproducibility standard deviations for the brands in this study were estimated from simple linear regressions of the mean and reproducibility standard deviation of test samples in CRMs. Mean and reproducibility standard deviation were used as explanatory and independent variables, respectively. Reproducibility standard deviations for brands in this study were calculated from the relevant simple linear regression using the mean value from five averaged data points from each sampling by constituents and smoking regimes.

\section{RESULTS}

Since two brands for 1,3-butadiene (No. 2, 3), three brands for benzene (No. 2, 3, 8), three brands for formaldehyde (No. 2, 4, 5), and two brands for acrolein (No. 2, 3) included yields were below the limit of detection or limit of quantification under the ISO smoking regime, they were excluded from the data analysis.

Mean, standard deviation, and CV by brands, constituents under ISO and HCI smoking regimes are shown in Tables 2-1 and 2-2, respectively. Mean, standard deviation, and $\mathrm{CV}$ for physical properties and constituents found in the tobacco filler blends are shown in Table 2-3. CV values varied largely by brands, constituents, and smoking regimes. In particular, $\mathrm{CV}$ values of the yields of $\mathrm{NNN}$ and NNK in smoke and tobacco filler blend showed the highest variation among all the constituents in this study. CV values of the yield of $\mathrm{NNN}$ in tobacco filler blend were beyond $20 \%$ for ten out of nineteen brands.

Pearson's correlation coefficients between cigarette design parameters and the yields of TPM, "tar", and nicotine are shown in Tables 3-1, 3-2, and 3-3, respectively. The number of brands with Pearson's correlation coefficients below -0.7 between filter ventilation and the yield of TPM, "tar", and nicotine were twelve, twelve, and eight, respectively, under the ISO smoking regime. Only two brands had Pearson's correlation coefficients above 0.7 between the yield of nicotine in the tobacco filler blend and the smoke under the ISO smoking regime and three under the HCI smoking regime as shown in Table 3-3. Pearson's correlation coefficients relating the constituents in the smoke for the nineteen brands and brand No. 20 are shown in Table 4. Cigarettes from brand No. 20 were the monitor cigarettes used to check the stability of the measurement. The number of brands with Pearson's correlation coefficients above 0.7 was thirteen under the ISO smoking regime and eleven under the HCI smoking regime for benzo $[a]$ pyrene. The number of brands with Pearson's correlation coefficients above 0.7 was nine under the HCI smoking regime for 1,3-butadiene. Pearson's correlation coefficients between con-stituents in the tobacco filler blend and in the smoke are shown in Table 5-1 and 5-2. The number of brands with Pearson's correlation coefficients above 0.7 between NNN and NNK in tobacco filler blend and in smoke was thirteen and nine, respectively, under the ISO and HCI smoking regimes as shown in Table 5-1. On the other hand, only a limited number of brands showed Pearson's correlation coefficients above 0.7 between total reducing sugar levels in the tobacco filler blend and the yield of formaldehyde in the smoke as shown in Table 5-2; additionally, the trends were largely different between the two smoking regimes. Pearson's correlation coefficients between the amount of charcoal in the filter and yields of constituents, namely 1,3butadiene, benzene, formaldehyde, acetaldehyde, and acrolein, are shown in Table 6. Brand No. 13 was the only brand that showed Pearson's correlation coefficients above 0.7 for five constituents under the ISO smoking regime. 


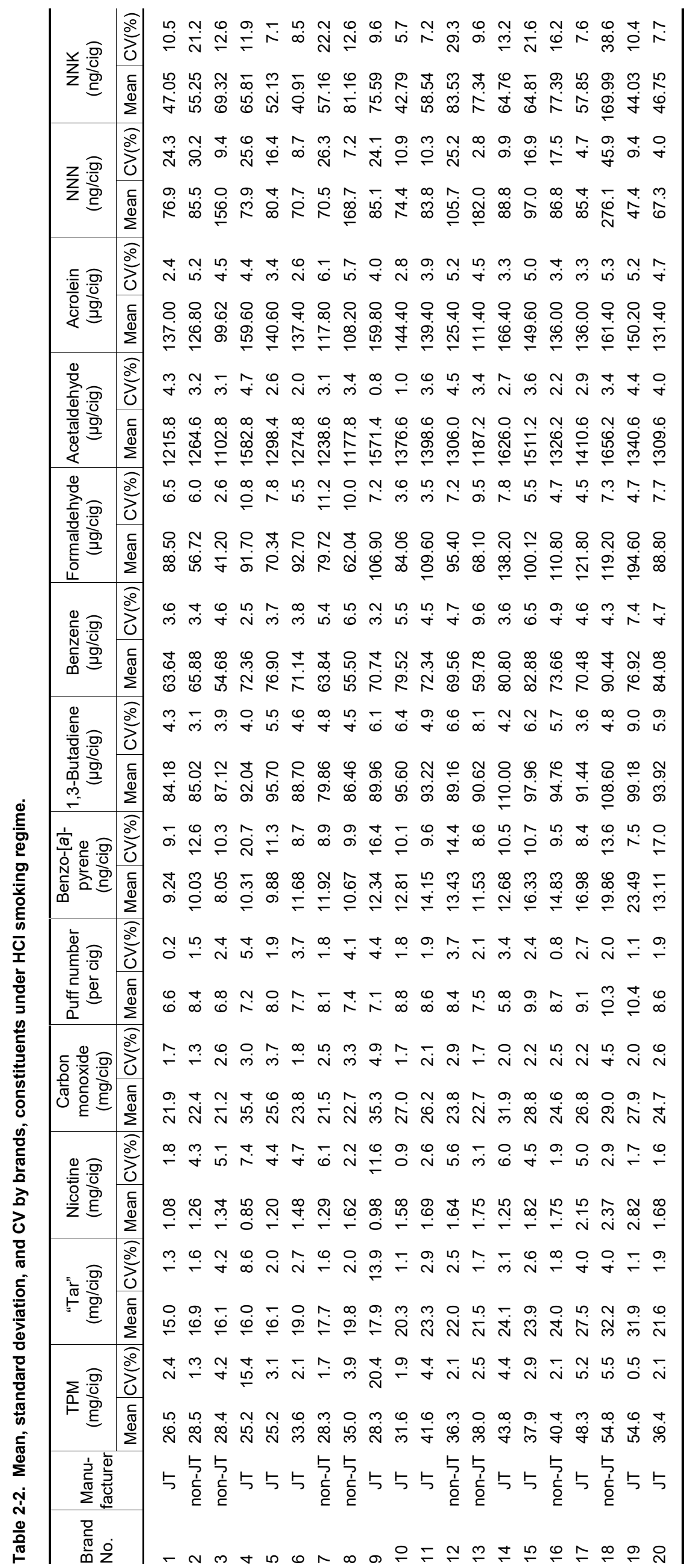




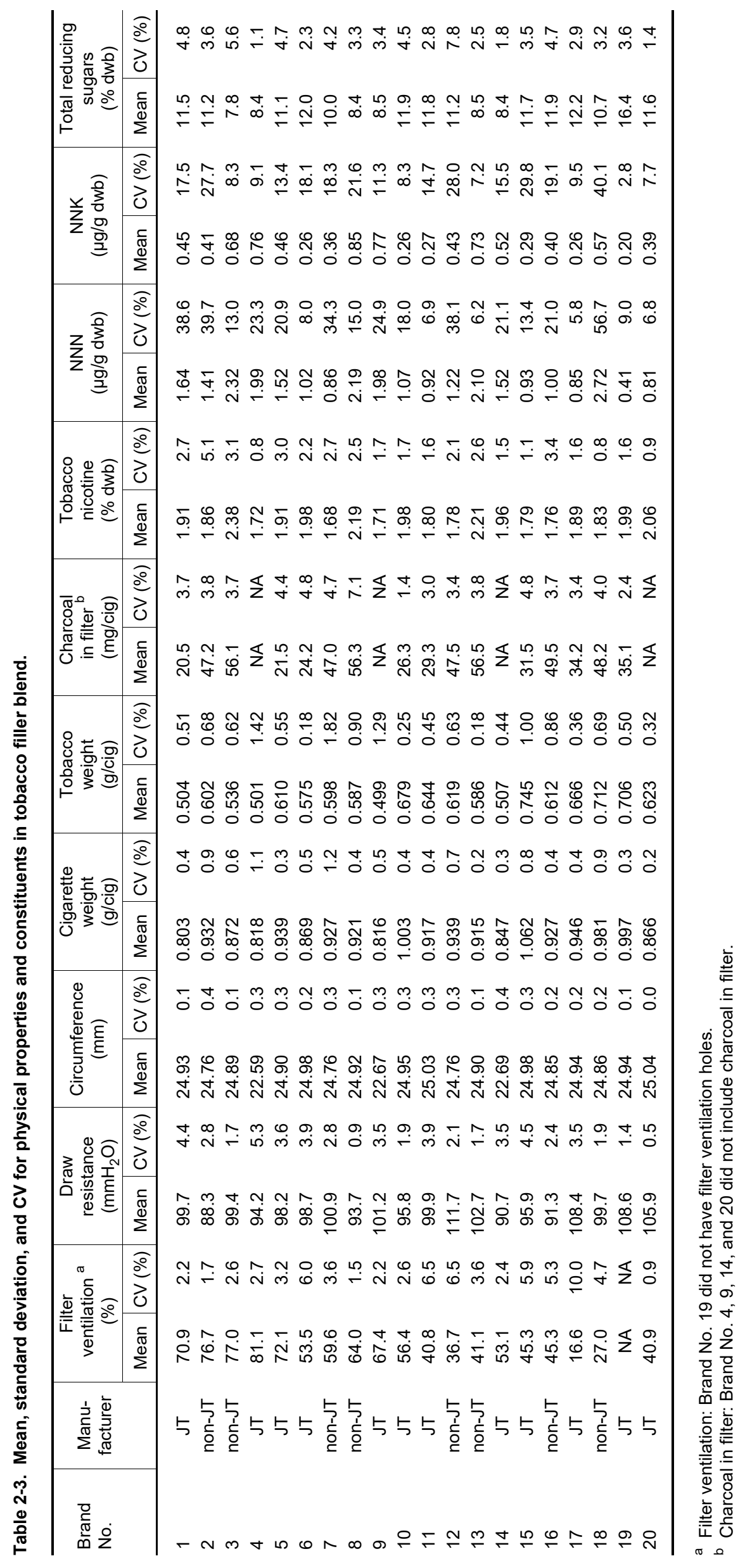




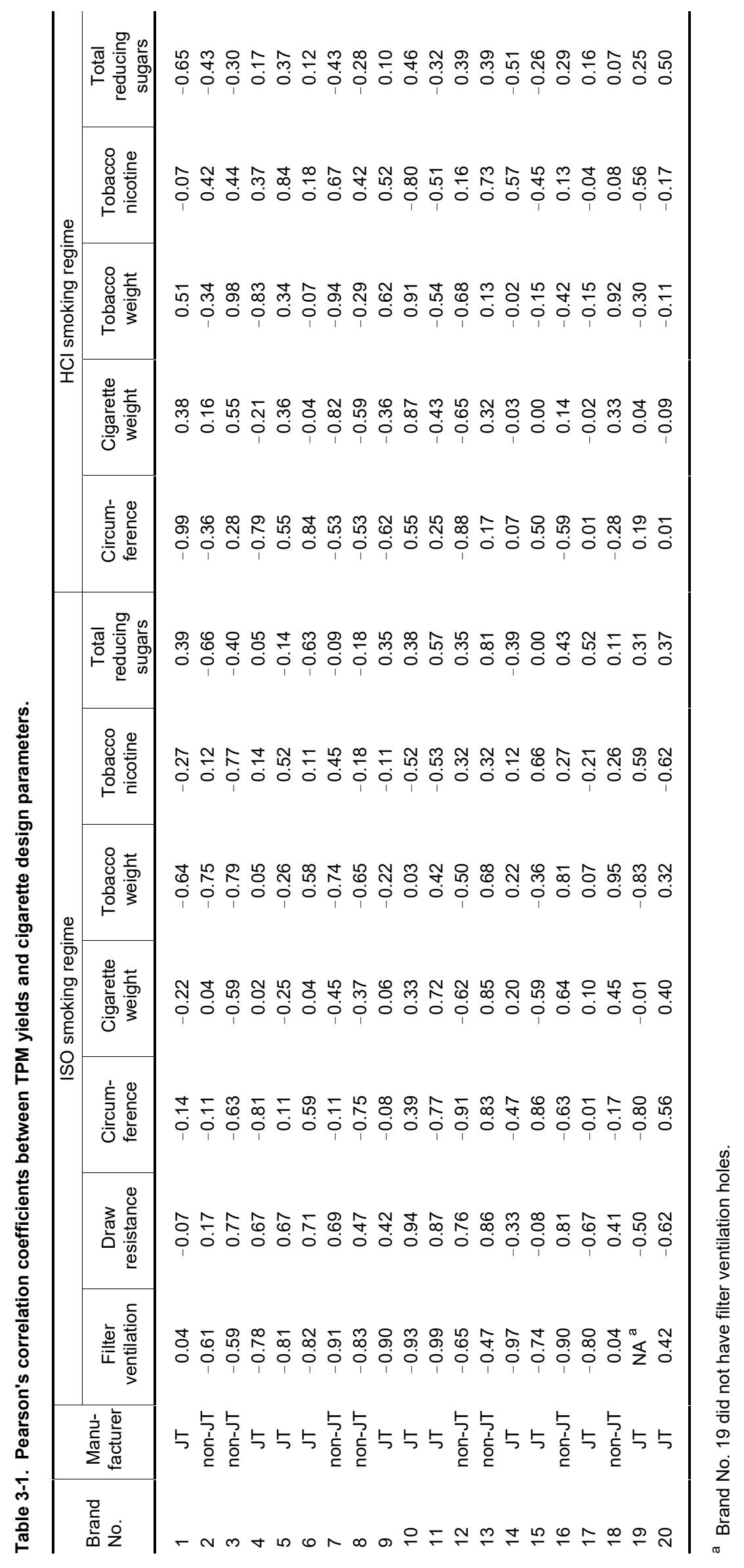


Table 3-2. Pearson's correlation coefficients between "tar" yields and cigarette design parameters.

\begin{tabular}{|c|c|c|c|c|c|c|c|c|c|c|c|c|c|}
\hline \multirow[b]{2}{*}{$\begin{array}{l}\text { Brand } \\
\text { No. }\end{array}$} & \multirow[b]{2}{*}{$\begin{array}{c}\text { Manu- } \\
\text { facturer }\end{array}$} & \multicolumn{7}{|c|}{ ISO smoking regime } & \multicolumn{5}{|c|}{$\mathrm{HCl}$ smoking regime } \\
\hline & & $\begin{array}{l}\text { Filter } \\
\text { venti- } \\
\text { lation }\end{array}$ & $\begin{array}{l}\text { Draw } \\
\text { resis- } \\
\text { tance }\end{array}$ & $\begin{array}{l}\text { Circum- } \\
\text { ference }\end{array}$ & $\begin{array}{c}\text { Cigarette } \\
\text { weight }\end{array}$ & $\begin{array}{c}\text { Tobacco } \\
\text { weight }\end{array}$ & $\begin{array}{l}\text { Tobacco } \\
\text { nicotine }\end{array}$ & $\begin{array}{c}\text { Total } \\
\text { reducing } \\
\text { sugars }\end{array}$ & $\begin{array}{l}\text { Circum- } \\
\text { ference }\end{array}$ & $\begin{array}{c}\text { Cigarette } \\
\text { weight }\end{array}$ & $\begin{array}{c}\text { Tobacco } \\
\text { weight }\end{array}$ & $\begin{array}{l}\text { Tobacco } \\
\text { nicotine }\end{array}$ & $\begin{array}{c}\text { Total } \\
\text { reducing } \\
\text { sugars }\end{array}$ \\
\hline 1 & JT & 0.30 & -0.13 & -0.43 & 0.26 & -0.09 & -0.59 & 0.19 & -0.44 & 0.30 & 0.09 & -0.70 & -0.12 \\
\hline 2 & non-JT & -0.63 & 0.20 & -0.19 & -0.02 & -0.77 & 0.11 & -0.62 & 0.11 & 0.23 & -0.68 & 0.19 & -0.74 \\
\hline 3 & non-JT & -0.41 & 0.61 & -0.72 & -0.52 & -0.70 & -0.69 & -0.51 & 0.28 & 0.58 & 0.97 & 0.56 & -0.21 \\
\hline 4 & JT & -0.73 & 0.57 & -0.84 & 0.11 & 0.14 & 0.06 & 0.14 & -0.70 & -0.29 & -0.88 & 0.37 & 0.17 \\
\hline 5 & JT & -0.84 & 0.72 & 0.06 & -0.29 & -0.30 & 0.45 & -0.18 & 0.63 & 0.64 & 0.73 & 0.67 & 0.34 \\
\hline 6 & $\mathrm{JT}$ & -0.85 & 0.76 & 0.54 & 0.06 & 0.65 & 0.09 & -0.69 & 0.79 & -0.13 & -0.26 & 0.28 & 0.35 \\
\hline 7 & non-JT & -0.93 & 0.75 & -0.02 & -0.42 & -0.76 & 0.51 & 0.00 & -0.92 & -0.62 & -0.74 & 0.01 & -0.84 \\
\hline 8 & non-JT & -0.87 & 0.59 & -0.82 & -0.38 & -0.68 & -0.26 & -0.25 & -0.33 & -0.20 & 0.28 & 0.32 & -0.47 \\
\hline 9 & JT & -0.84 & 0.42 & -0.14 & -0.09 & -0.32 & -0.06 & 0.22 & -0.63 & -0.45 & 0.54 & 0.51 & 0.00 \\
\hline 10 & JT & -0.96 & 0.91 & 0.33 & 0.27 & 0.03 & -0.48 & 0.33 & 0.19 & 0.53 & 0.69 & -0.76 & 0.16 \\
\hline 11 & $\mathrm{JT}$ & -0.99 & 0.93 & -0.76 & 0.77 & 0.52 & -0.60 & 0.46 & 0.24 & -0.45 & -0.22 & -0.22 & -0.69 \\
\hline 12 & non-JT & -0.69 & 0.73 & -0.95 & -0.67 & -0.52 & 0.23 & 0.24 & -0.90 & -0.69 & -0.51 & 0.27 & 0.19 \\
\hline 13 & non-JT & -0.49 & 0.88 & 0.85 & 0.79 & 0.64 & 0.23 & 0.74 & 0.36 & 0.68 & 0.35 & 0.80 & 0.65 \\
\hline 14 & JT & -0.97 & -0.25 & -0.52 & 0.16 & 0.23 & 0.06 & -0.29 & -0.35 & 0.20 & 0.08 & 0.25 & -0.63 \\
\hline 15 & $\mathrm{JT}$ & -0.78 & -0.02 & 0.80 & -0.69 & -0.49 & 0.72 & -0.10 & 0.83 & -0.10 & -0.02 & -0.11 & -0.01 \\
\hline 16 & non-JT & -0.91 & 0.79 & -0.67 & 0.65 & 0.81 & 0.27 & 0.47 & -0.77 & 0.25 & 0.35 & 0.73 & 0.66 \\
\hline 17 & JT & -0.84 & -0.67 & 0.03 & 0.07 & 0.07 & -0.28 & 0.57 & 0.17 & -0.25 & -0.40 & -0.26 & 0.40 \\
\hline 18 & non-JT & 0.00 & 0.50 & -0.23 & 0.41 & 0.97 & 0.17 & 0.17 & -0.17 & 0.46 & 0.94 & 0.04 & 0.09 \\
\hline 19 & $\mathrm{JT}$ & $N A^{a}$ & -0.34 & -0.89 & 0.29 & -0.99 & 0.59 & -0.06 & -0.33 & 0.47 & -0.46 & -0.01 & -0.07 \\
\hline 20 & JT & 0.17 & -0.53 & 0.47 & 0.17 & 0.05 & -0.52 & 0.38 & 0.27 & -0.11 & -0.16 & -0.09 & 0.68 \\
\hline
\end{tabular}

a Brand No. 19 did not have filter ventilation holes.

Table 3-3. Pearson's correlation coefficients between nicotine yields and cigarette design parameters.

\begin{tabular}{|c|c|c|c|c|c|c|c|c|c|c|c|c|c|}
\hline \multirow[b]{2}{*}{$\begin{array}{l}\text { Brand } \\
\text { No. }\end{array}$} & \multirow[b]{2}{*}{$\begin{array}{l}\text { Manu- } \\
\text { facturer }\end{array}$} & \multicolumn{7}{|c|}{ ISO smoking regime } & \multicolumn{5}{|c|}{$\mathrm{HCl}$ smoking regime } \\
\hline & & $\begin{array}{l}\text { Filter } \\
\text { Venti- } \\
\text { lation }\end{array}$ & $\begin{array}{l}\text { Draw } \\
\text { Resis- } \\
\text { tance }\end{array}$ & $\begin{array}{l}\text { Circum- } \\
\text { ference }\end{array}$ & $\begin{array}{c}\text { Cigarette } \\
\text { weight }\end{array}$ & $\begin{array}{c}\text { Tobacco } \\
\text { weight }\end{array}$ & $\begin{array}{l}\text { Tobacco } \\
\text { nicotine }\end{array}$ & $\begin{array}{c}\text { Total } \\
\text { reducing } \\
\text { sugars }\end{array}$ & $\begin{array}{l}\text { Circum- } \\
\text { ference }\end{array}$ & $\begin{array}{c}\text { Cigarette } \\
\text { weight }\end{array}$ & $\begin{array}{c}\text { Tobacco } \\
\text { weight }\end{array}$ & $\begin{array}{l}\text { Tobacco } \\
\text { nicotine }\end{array}$ & $\begin{array}{c}\text { Total } \\
\text { reducing } \\
\text { sugars }\end{array}$ \\
\hline 1 & $\mathrm{JT}$ & -0.65 & 0.42 & -0.14 & -0.66 & -0.74 & 0.57 & 0.22 & 0.92 & -0.38 & -0.35 & 0.03 & 0.29 \\
\hline 2 & non-JT & -0.67 & 0.38 & -0.20 & -0.05 & -0.92 & 0.23 & -0.69 & 0.01 & 0.31 & -0.76 & 0.61 & -0.81 \\
\hline 3 & non-JT & -0.39 & 0.54 & -0.70 & -0.46 & -0.79 & -0.53 & -0.36 & 0.10 & 0.54 & 0.73 & 0.67 & -0.14 \\
\hline 4 & JT & -0.66 & 0.45 & -0.92 & 0.07 & 0.07 & -0.07 & 0.36 & -0.63 & -0.10 & -0.84 & 0.35 & 0.19 \\
\hline 5 & JT & -0.67 & 0.53 & 0.21 & -0.15 & -0.22 & 0.70 & -0.16 & 0.79 & 0.74 & 0.77 & 0.66 & 0.76 \\
\hline 6 & $\mathrm{JT}$ & -0.79 & 0.60 & 0.63 & -0.13 & 0.43 & 0.33 & -0.50 & 0.71 & -0.23 & -0.29 & 0.45 & 0.42 \\
\hline 7 & non-JT & -0.75 & 0.44 & -0.47 & -0.56 & -0.69 & 0.23 & -0.45 & -0.56 & -0.36 & -0.45 & -0.08 & -0.54 \\
\hline 8 & non-JT & -0.71 & 0.32 & -0.62 & -0.44 & -0.69 & -0.07 & -0.01 & -0.03 & 0.70 & 0.85 & -0.03 & -0.78 \\
\hline 9 & JT & -0.96 & 0.56 & 0.17 & 0.09 & -0.24 & -0.35 & 0.37 & -0.60 & -0.49 & 0.60 & 0.49 & -0.03 \\
\hline 10 & JT & -0.95 & 0.75 & 0.27 & 0.02 & -0.02 & -0.21 & 0.34 & 0.61 & 0.02 & -0.41 & 0.20 & 0.64 \\
\hline 11 & JT & -0.91 & 0.71 & -0.67 & 0.69 & 0.50 & -0.18 & 0.63 & 0.34 & -0.12 & 0.53 & 0.17 & -0.98 \\
\hline 12 & non-JT & -0.69 & 0.54 & -0.95 & -0.76 & -0.55 & 0.01 & -0.10 & -0.97 & -0.81 & -0.63 & 0.00 & -0.06 \\
\hline 13 & non-JT & -0.29 & 0.71 & 0.68 & 0.83 & 0.52 & 0.45 & 0.74 & 0.06 & 0.59 & 0.03 & 0.79 & 0.42 \\
\hline 14 & JT & -0.94 & -0.50 & -0.30 & 0.31 & 0.29 & 0.30 & -0.49 & 0.02 & 0.57 & 0.59 & 0.56 & -0.40 \\
\hline 15 & $\mathrm{JT}$ & -0.44 & -0.38 & 0.83 & -0.62 & -0.49 & 0.40 & -0.36 & 0.95 & -0.16 & 0.07 & 0.21 & 0.24 \\
\hline 16 & non-JT & -0.93 & 0.83 & -0.71 & 0.66 & 0.82 & 0.31 & 0.54 & -0.21 & -0.08 & 0.27 & 0.79 & -0.06 \\
\hline 17 & JT & -0.53 & -0.70 & -0.17 & 0.04 & -0.10 & -0.04 & 0.67 & 0.14 & -0.16 & -0.30 & -0.17 & 0.21 \\
\hline 18 & non-JT & -0.10 & -0.14 & -0.06 & 0.25 & 0.57 & 0.68 & -0.32 & 0.24 & 0.38 & 0.38 & 0.52 & -0.65 \\
\hline 19 & $\mathrm{JT}$ & $N A^{a}$ & -0.53 & -0.90 & 0.37 & -0.75 & 0.72 & -0.01 & -0.95 & 0.56 & -0.35 & 0.97 & -0.41 \\
\hline 20 & JT & 0.74 & -0.79 & -0.02 & 0.78 & 0.98 & -0.85 & -0.22 & 0.56 & 0.65 & 0.64 & -0.44 & 0.11 \\
\hline
\end{tabular}

a Brand No. 19 did not have filter ventilation holes. 


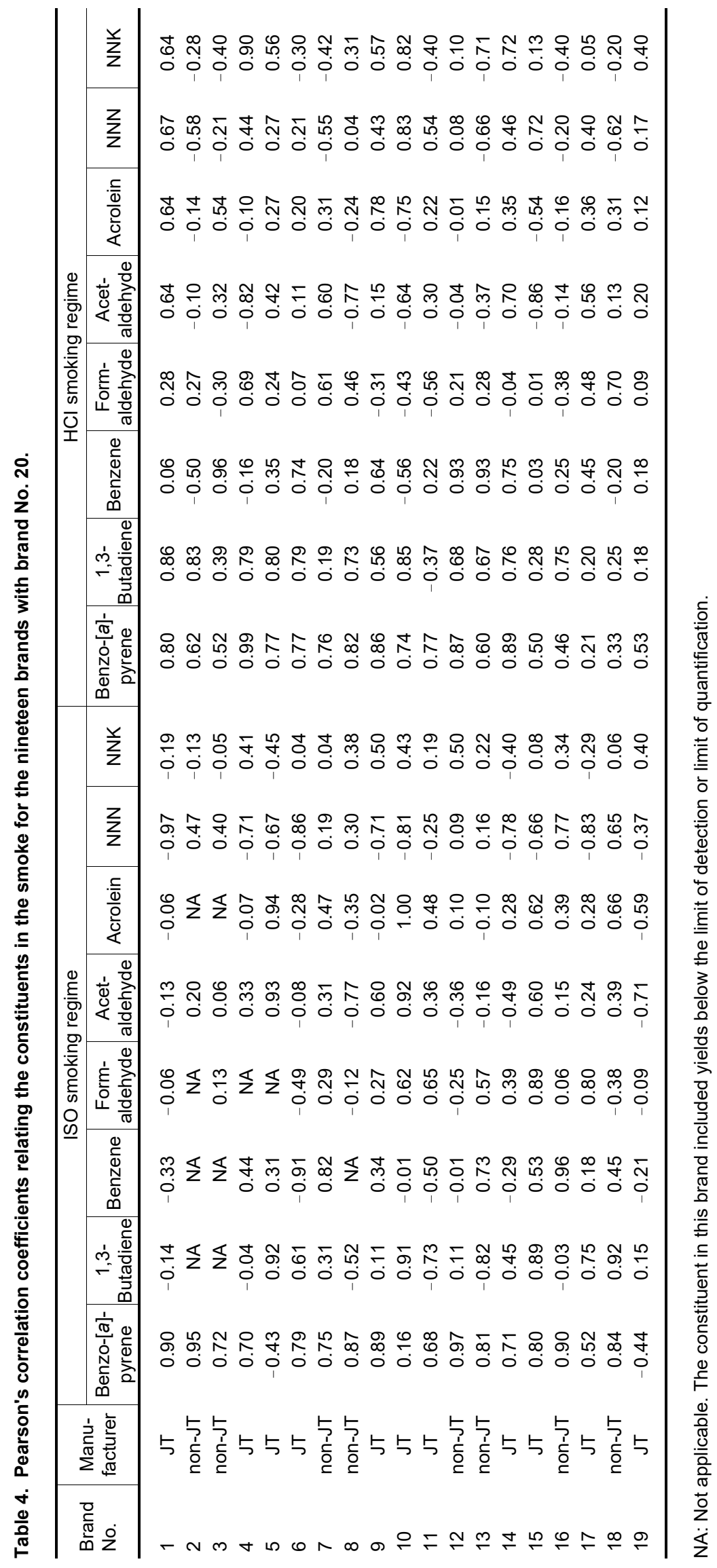


Table 5-1. Pearson's correlation coefficients between NNN and NNK in tobacco filler blend and those in smoke.

\begin{tabular}{|c|c|c|c|c|c|}
\hline \multirow{2}{*}{$\begin{array}{l}\text { Brand } \\
\text { No. }\end{array}$} & \multirow{2}{*}{$\begin{array}{l}\text { Manu- } \\
\text { facturer }\end{array}$} & \multicolumn{2}{|c|}{$\begin{array}{l}\text { ISO smoking } \\
\text { regime }\end{array}$} & \multicolumn{2}{|c|}{$\begin{array}{l}\mathrm{HCl} \text { smoking } \\
\text { regime }\end{array}$} \\
\hline & & NNN & NNK & NNN & NNK \\
\hline 1 & $\mathrm{JT}$ & 0.92 & 0.85 & 0.98 & 0.76 \\
\hline 2 & non-JT & 0.92 & 0.98 & 0.99 & 0.98 \\
\hline 3 & non-JT & 0.90 & 0.29 & 0.84 & 0.76 \\
\hline 4 & JT & 0.82 & 0.00 & 0.96 & 0.26 \\
\hline 5 & $\mathrm{JT}$ & 0.99 & 0.73 & 0.96 & 0.73 \\
\hline 6 & $\mathrm{JT}$ & 0.58 & -0.23 & 0.48 & -0.10 \\
\hline 7 & non-JT & 0.83 & 0.25 & 0.97 & 0.51 \\
\hline 8 & non-JT & 0.71 & 0.76 & 0.87 & 0.93 \\
\hline 9 & JT & 0.87 & 0.01 & 0.92 & 0.81 \\
\hline 10 & JT & 0.25 & -0.49 & -0.05 & -0.79 \\
\hline 11 & JT & 0.66 & 0.03 & 0.62 & 0.57 \\
\hline 12 & non-JT & 0.91 & 0.96 & 0.91 & 0.97 \\
\hline 13 & non-JT & 0.42 & 0.75 & 0.74 & 0.65 \\
\hline 14 & JT & 0.93 & 0.50 & 0.72 & 0.67 \\
\hline 15 & JT & 0.84 & 0.82 & 0.93 & 0.92 \\
\hline 16 & non-JT & 0.91 & 0.76 & 0.93 & 0.86 \\
\hline 17 & JT & 0.19 & 0.27 & -0.21 & 0.51 \\
\hline 18 & non-JT & 0.98 & 0.97 & 0.97 & 0.93 \\
\hline 19 & $\mathrm{JT}$ & 0.53 & 0.27 & -0.11 & 0.24 \\
\hline 20 & JT & 0.59 & -0.59 & -0.66 & -0.97 \\
\hline
\end{tabular}

The number of brands with Pearson's correlation coefficients below -0.7 for the relationship between the yield of charcoal in the filter and the yields of constituents were three to four, regardless of the constituents, under the ISO smoking regime. The number of brands was lower under the HCI smoking regime. Mean, maximum, and minimum $\mathrm{CV}$ values associated with both cigarette manufacturing over ten months and measurements at different laboratories are shown in Table 7. Coefficient of determinations for regression models of 1,3-butadiene, benzene, acetaldehyde, and acrolein under the HCI smoking regime were 0.0727 , $0.461,0.1734$, and 0.0596 , respectively. Therefore, CV values were not calculated for four constituents under the HCI smoking regime. Coefficient of determinations was higher than 0.9 , except for formaldehyde, under the HCI smoking regime. The coefficient of determination for formaldehyde under the HCI smoking regime was 0.7092 . The grand mean of CV values of the yield of formaldehyde showed the highest values among the constituents.

\section{DISCUSSION}

\section{Cigarette manufacturing}

The difference between the average yields of "tar" and nicotine in each brand in this study and their levels displayed on the package were compared with the confidence intervals over a period of time in ISO 8243 (16). The differences were within the range of confidence intervals except for the yields of nicotine in brand No. 13. Physical properties of JT brands were within the range of cigarette specification allowances. Therefore, this study provides information regarding normal cigarette manufacturing.
The influence of measurement over the 10-month period variations in the yields of the constituents in smoke

Variation associated with measurement, out of the total variation, was evaluated by calculating Pearson's correlation coefficients by constituents and smoking regimes between monitor cigarette brand No. 20 and nineteen commercial cigarette brands. Thirteen brands had Pearson's correlation coefficients above 0.7 under the ISO smoking regime and eleven under the HCI smoking regime for benzo $[a]$ pyrene. This means that the variation in the yields of benzo $[a]$ pyrene in smoke was largely influenced by the measurement. When benzo[a]pyrene was measured with HPLC-FLD, the difference in peak integration between laboratories affected the yields and reproducibility of the measurements (28). Peak integration in the measurement of benzo[ $a]$ pyrene in smoke might be one factor causing the variation. The number of brands with Pearson's correlation coefficients above 0.7 was nine under the HCI smoking regime for 1,3-butadiene. On the other hand, the number of brands was lower under the ISO smoking regime. In addition, benzene, which was measured with 1,3-butadiene using the same method, did not show the same trend. Therefore, measurement of the yields of 1,3-butadiene in smoke had some issues that have to be improved, as reported by ELDRIDGE et al. (7). Variation associated with measurement was not the main source of variation for the yields of the constituents in smoke, except benzo[ $a]$ pyrene and 1,3-butadiene because Pearson's correlation coefficients were not high. Monitoring the variation in the yields of the constituents in smoke over time, evaluates the variation

Table 5-2. Pearson's correlation coefficients between total reducing sugar levels in tobacco filler blend and the yield of formaldehyde in smoke.

\begin{tabular}{l|c|c|c}
\hline \multirow{2}{*}{$\begin{array}{l}\text { Brand } \\
\text { No. }\end{array}$} & $\begin{array}{c}\text { Manu- } \\
\text { facturer }\end{array}$ & $\begin{array}{c}\text { ISO smoking } \\
\text { regime }\end{array}$ & $\begin{array}{c}\text { HCl smoking } \\
\text { regime }\end{array}$ \\
\cline { 3 - 4 } 1 & Formaldehyde & Formaldehyde \\
\hline 2 & JT & 0.56 & 0.73 \\
3 & non-JT & NA & 0.18 \\
4 & non-JT & 0.80 & -0.20 \\
5 & JT & NA & 0.30 \\
6 & JT & NA & 0.93 \\
7 & JT & -0.64 & 0.82 \\
8 & non-JT & 0.53 & 0.82 \\
9 & non-JT & -0.27 & -0.54 \\
10 & JT & 0.52 & 0.14 \\
11 & JT & 0.80 & -0.56 \\
12 & JT & 0.32 & -0.54 \\
13 & non-JT & 0.05 & 0.29 \\
14 & non-JT & -0.33 & -0.41 \\
15 & JT & 0.05 & -0.57 \\
16 & JT & 0.09 & -0.43 \\
17 & non-JT & 0.17 & 0.18 \\
18 & JT & -0.12 & 0.94 \\
19 & non-JT & -0.21 & -0.35 \\
20 & JT & 0.11 & 0.90 \\
\hline & JT & -0.54 & -0.66 \\
\hline
\end{tabular}

NA: Not applicable. The constituent in this brand included yields below the limit of detection or limit of quantification. 
Table 6. Pearson's correlation coefficients between the amount of charcoal in the filter and yields of constituents in the vapor phase. In addition, brand No 4, 9, 14, and 20 did not include charcoal in the filter.

\begin{tabular}{|c|c|c|c|c|c|c|c|c|c|c|c|}
\hline \multirow{2}{*}{$\begin{array}{l}\text { Brand } \\
\text { No. }\end{array}$} & \multirow{2}{*}{$\begin{array}{l}\text { Manu- } \\
\text { facturer }\end{array}$} & \multicolumn{5}{|c|}{ ISO smoking regime } & \multicolumn{5}{|c|}{$\mathrm{HCl}$ smoking regime } \\
\hline & & $\begin{array}{c}1,3- \\
\text { Butadiene }\end{array}$ & Benzene & $\begin{array}{c}\text { Form- } \\
\text { aldehyde }\end{array}$ & $\begin{array}{c}\text { Acet- } \\
\text { aldehyde }\end{array}$ & Acrolein & $\begin{array}{c}1,3- \\
\text { Butadiene }\end{array}$ & Benzene & $\begin{array}{c}\text { Form- } \\
\text { aldehyde }\end{array}$ & $\begin{array}{c}\text { Acet- } \\
\text { aldehyde }\end{array}$ & Acrolein \\
\hline 1 & JT & -0.62 & -0.94 & -0.30 & -0.62 & -0.91 & 0.32 & -0.37 & 0.17 & 0.22 & 0.76 \\
\hline 2 & non-JT & NA & NA & NA & 0.57 & NA & -0.09 & 0.79 & -0.52 & -0.68 & 0.07 \\
\hline 3 & non-JT & NA & NA & 0.03 & 0.11 & NA & -0.82 & 0.00 & 0.88 & 0.60 & 0.56 \\
\hline 4 & JT & NA & NA & NA & NA & NA & NA & NA & NA & NA & NA \\
\hline 5 & JT & 0.59 & 0.12 & NA & 0.36 & 0.37 & 0.21 & -0.04 & 0.00 & 0.08 & -0.15 \\
\hline 6 & JT & 0.36 & -0.28 & -0.23 & -0.18 & -0.21 & -0.12 & -0.43 & -0.46 & -0.97 & -0.69 \\
\hline 7 & non-JT & -0.72 & -0.80 & -0.41 & -0.81 & -0.87 & 0.70 & 0.34 & -0.60 & -0.46 & -0.81 \\
\hline 8 & non-JT & 0.48 & NA & 0.49 & 0.19 & 0.42 & -0.58 & 0.72 & 0.96 & 0.22 & 0.58 \\
\hline 9 & JT & NA & NA & NA & NA & NA & NA & NA & NA & NA & NA \\
\hline 10 & $\mathrm{JT}$ & -0.22 & -0.22 & 0.59 & 0.11 & 0.04 & -0.15 & -0.48 & -0.50 & -0.56 & -0.51 \\
\hline 11 & JT & 0.43 & -0.29 & 0.98 & 0.79 & 0.86 & 0.00 & -0.21 & -0.17 & 0.92 & 0.93 \\
\hline 12 & non-JT & -0.71 & -0.33 & -0.81 & -0.97 & -0.60 & -0.44 & -0.56 & 0.25 & 0.14 & 0.38 \\
\hline 13 & non-JT & -0.80 & -0.85 & -0.85 & -0.95 & -0.84 & 0.30 & -0.12 & -0.74 & -0.73 & -0.96 \\
\hline 14 & $\mathrm{JT}$ & NA & NA & NA & NA & NA & NA & NA & NA & NA & NA \\
\hline 15 & JT & -0.28 & -0.35 & -0.27 & -0.10 & -0.03 & 0.12 & 0.04 & -0.11 & -0.21 & -0.07 \\
\hline 16 & non-JT & 0.28 & -0.67 & -0.71 & -0.47 & -0.51 & 0.34 & 0.00 & -0.60 & -0.73 & -0.24 \\
\hline 17 & JT & 0.73 & -0.57 & 0.12 & -0.41 & -0.40 & -0.79 & -0.82 & 0.05 & 0.00 & -0.48 \\
\hline 18 & non-JT & 0.25 & 0.74 & -0.08 & 0.75 & 0.80 & -0.26 & 0.70 & 0.59 & 0.37 & 0.92 \\
\hline 19 & JT & 0.53 & 0.63 & -0.91 & 0.21 & -0.11 & 0.24 & -0.40 & -0.27 & -0.59 & -0.63 \\
\hline 20 & JT & NA & NA & NA & NA & NA & NA & NA & NA & NA & NA \\
\hline
\end{tabular}

NA: Not applicable. The constituent in this brand included yields below the limit of detection or limit of quantification.

associated with cigarette manufacturing and measurement simultaneously. Therefore, it is important to measure monitor cigarettes along with commercial cigarette brands to understand the stability of the measurement.

\section{Variation of NNN and NNK yields in smoke}

$\mathrm{CV}$ values for the yields of NNN and NNK in smoke and tobacco filler blend showed the highest variation among the constituents in this study. In addition, NNN and NNK yields in smoke correlated well with those in the tobacco filler blend. Other studies also report these relationships (7, 9, and 12). MOLDOVEANU and BORGERDING have studied the formation of NNN and NNK in detail (29). As typical examples, brands No. 18 and No. 1 are shown in Figure 1 and Figure 2, respectively. For brand No. 18, the first to third batches and fourth to fifth batches apparently contained different yields in both smoke and tobacco filler blend. In contrast, it seemed that the data for brand No. 1 showed random variations which might come from normal manufacturing without a major blend composition change. The example of brand No. 18 indicates the importance of understanding the variation in the yields of smoke constituents over a period of time, rather than at one point in time.

\section{Variation in formaldehyde yields in smoke}

PARRISH and HARWARD have shown that tobaccos with high levels of total reducing sugars tend to give high yields of formaldehyde in smoke (30). Only limited brands showed Pearson's correlation coefficients above 0.7 between total reducing sugar levels in tobacco filler blend and the yields of formaldehyde in smoke, and this tendency was largely different between the two smoking regimes. For brand No. 1, the yields of NNN in tobacco filler blend ranged from 1.1 to $2.6 \mu \mathrm{g} / \mathrm{g}$, which is a 2.4 -fold change between batches. On the other hand, the total reducing sugar levels in tobacco filler blend ranged from 10.8 to $12.2 \%$, only a 1.1 -fold change. This small range within a given brand may not be adequate to demonstrate the relationship. Thus, variation of levels of total reducing sugar in tobacco filler blend were not the main factor for the variation for the yields of formaldehyde in smoke. The variation for the yields of formaldehyde in smoke might be

Table 7. Mean, maximum, and minimum CV values associated with both cigarette manufacturing over ten months and measurements at different laboratories. Values are given in percent (\%). Due to low coefficient of determinations for regression models of 1,3-butadiene, benzene, acetaldehyde, and acrolein under the $\mathrm{HCl}$ smoking regime, $\mathrm{CV}$ values were not calculated for these four constituents.

\begin{tabular}{l|c|c|c|c|c|c}
\hline \multirow{2}{*}{ Constituent } & \multicolumn{3}{|c|}{ ISO smoking regime } & \multicolumn{3}{c}{$\mathrm{HCl}$ smoking regime } \\
\cline { 2 - 7 } & Min & Mean & Max & Min & Mean & Max \\
\hline 1,3-Butadiene & 17.9 & 20.4 & 24.7 & NA & NA & NA \\
Benzene & 17.4 & 25.6 & 40.8 & NA & NA & NA \\
Formaldehyde & 16.3 & 28.4 & 57.1 & 21.9 & 22.9 & 24.5 \\
Acetaldehyde & 10.6 & 21.4 & 44.1 & NA & NA & NA \\
Acrolein & 13.7 & 27.2 & 55.2 & NA & NA & NA \\
NNN & 12.5 & 23.8 & 47.1 & 13.9 & 23.7 & 47.7 \\
NNK & 15.2 & 24.4 & 44.0 & 17.8 & 22.4 & 41.6 \\
\hline
\end{tabular}

NA: Not Applicable. The constituent in this brand included yields below the limit of detection or limit of quantification. 


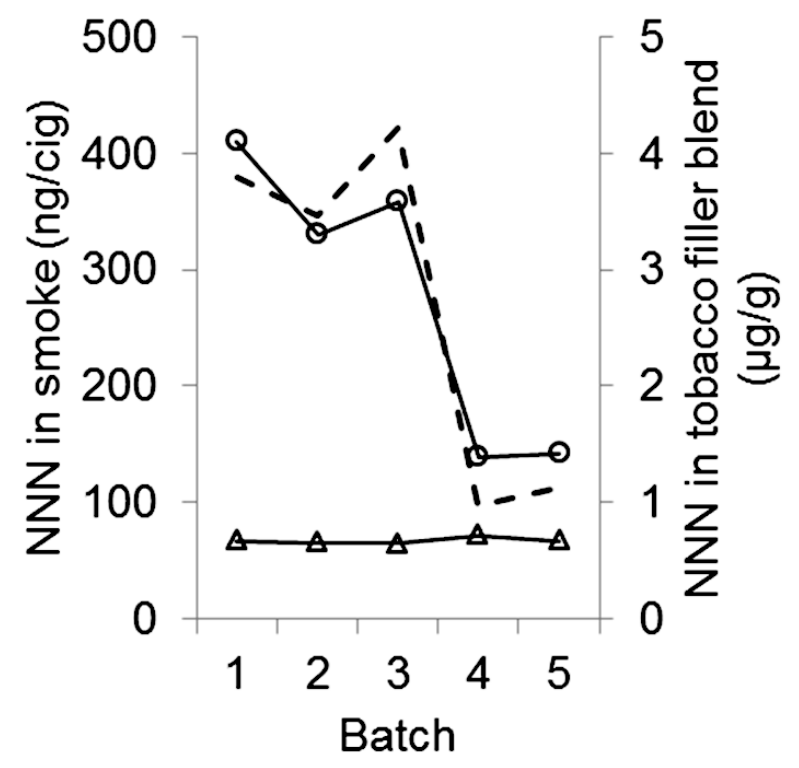

Figure 1. Trend of NNN in smoke and tobacco filler blend for brand No. 18.

-०-: NNN in smoke for brand No. 18 under $\mathrm{HCl}$ smoking regime; - : NNN in tobacco filler blend for brand No. 18;

$-\Delta-:$ NNN in smoke for brand No. 20 under $\mathrm{HCl}$ smoking regime.

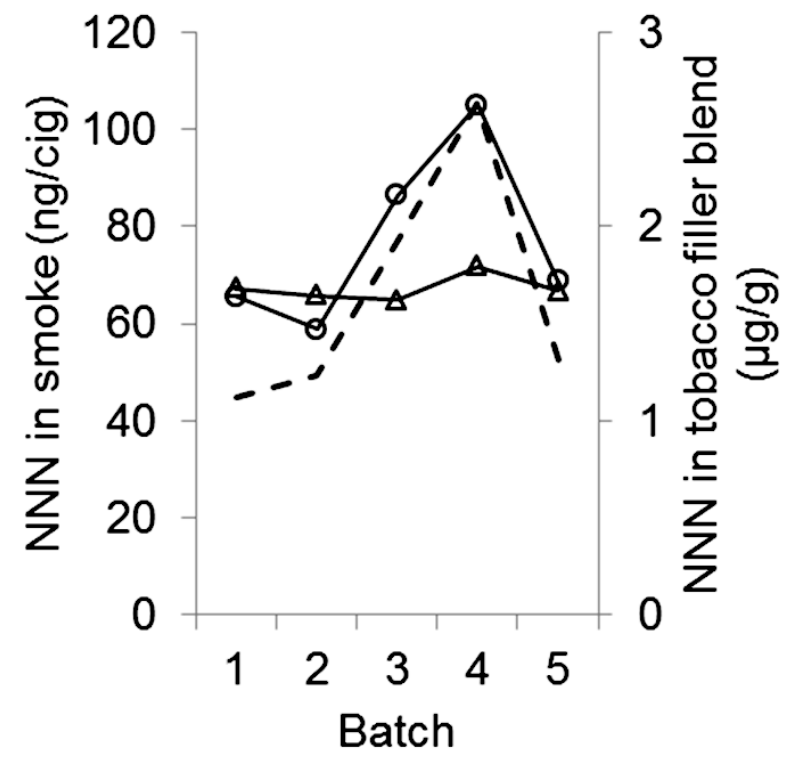

Figure 2. Trend of NNN in smoke and tobacco filler blend for brand No. 1.

-O-: NNN in smoke for brand No. 1 under $\mathrm{HCl}$ smoking regime; - : NNN in tobacco filler blend for brand No. 1;

$-\Delta-: \mathrm{NNN}$ in smoke for brand $\mathrm{No} .20$ under $\mathrm{HCl}$ smoking regime. explained by another factor or the combination of various factors.

\section{Charcoal filter and smoke constituents in vapor phase}

Activated charcoal is well known to have the potential to selectively adsorb many vapor phase constituents from mainstream smoke $(31,32)$. Brand No. 13 was the only brand which showed Pearson's correlation coefficients below -0.7 for all five constituents namely 1,3-butadiene, benzene, formaldehyde, acetaldehyde, and acrolein. The average amount of charcoal in the filter of this brand was $56.5 \mathrm{mg} / \mathrm{cig}$. Some brands also had included nearly the same amount of charcoal in filters, but they did not always show the same higher correlation seen with brand No. 13 . The effect of carbon in the filter can be influenced by many factors such as the weight of the carbon, surface area, and activity (33). Since average CV value for the amount of charcoal amount was $3.9 \%$, this small variation within a single brand may not be adequate to demonstrate the relationship. The effect of carbon in the filter has been reported by comparing two linear regressions which were established from a wide range of cigarette brands with and without charcoal in the filter on the Japanese market (34). By contrast, variation of the amount of charcoal in the filter within a given brand was not the main factor for the variation of five constituents in this study.

Variation in the yields of constituents in smoke over time associated with cigarette manufacturing and measurement at different laboratories

The cigarette itself and the laboratory measurements are two major sources of statistical variation. Both of them result in short and long-term fluctuations over time, while measurements also vary between laboratories, even for matched cigarette samples (16). Confidence intervals have not been set for the yields of constituents other than "tar", nicotine, and carbon monoxide under the ISO smoking regime. Thus, standard deviations associated with both cigarette manufacturing over ten months and measurements at different laboratories were calculated in this study. Since the yield of benzo[a]pyrene in smoke was not measured with CRM58, benzo[a]pyrene was excluded from this calculation. Since coefficient of determinations for regression models of 1,3-butadiene, benzene, acetaldehyde, and acrolein under the HCI smoking regime were 0.0727, $0.461,0.1734$, and 0.0596 , respectively, they were also excluded from this calculation. One of the reasons for the lower coefficient of determinations of constituents in the vapor phase is vent blocking of cigarettes, and it narrowed the range of yields of constituents for the cigarette brands in this study. For example, acetaldehyde yields ranged from $99.96 \mu \mathrm{g} / \mathrm{cig}$ to $694.21 \mu \mathrm{g} / \mathrm{cig}$ under the ISO smoking regime, and $836.47 \mu \mathrm{g} / \mathrm{cig}$ to $1605.8 \mu \mathrm{g} / \mathrm{cig}$ under the HCI smoking regime. The ratios of maximum yields to minimum yields under ISO and HCI smoking regimes were 6.9 and 1.9 , respectively. The grand mean of $\mathrm{CV}$ values for NNN and formaldehyde associated with both cigarette manufacturing over ten months and measurement at different laboratories under the ISO smoking regimes were $23.8 \%$ and $28.4 \%$ respectively. The grand mean of CV 
values for NNN and formaldehyde associated with both cigarette manufacturing over ten months and measurement at different laboratories under the HCI smoking regimes were $23.7 \%$ and $22.9 \%$ respectively. The grand mean of $\mathrm{CV}$ values for NNN and formaldehyde associated with cigarette manufacturing over ten months and measurement at the JT laboratory under the ISO smoking regimes were $18.4 \%$ and $13.1 \%$ respectively. The grand mean of CV values for $\mathrm{NNN}$ and formaldehyde associated with cigarette manufacturing over ten months and measurement at the JT laboratory under the HCI smoking regimes were $17.1 \%$ and $6.6 \%$ respectively. The grand mean of $\mathrm{CV}$ values of the yield of formaldehyde showed the highest increase among the constituents when the standard deviation associated with measurement between laboratories was added. This is based on the fact that formaldehyde showed the highest $\mathrm{CV}$ values for reproducibility among the constituents.

This study used the yields of constituents in smoke from cigarette brands during 2009 to 2010 that were on the Japanese market. Caution must prevail when information from this study is compared to similar information from cigarette brands of other markets which have been produced at different times. In order to set realistic and robust confidence intervals for constituents, it is important to take into account variations over time associated with cigarette manufacturing and variation associated with measurement within and between laboratories. Generating enough data through the global cooperation is also important to set confidence intervals.

\section{CONCLUSIONS}

This study provided the variation in the yields of constituents in smoke from commercial cigarette brands on the Japanese market under normal cigarette manufacturing. The nineteen commercial cigarette brands were sampled five times every two months from 2009 to 2010 . Target constituents were benzo[ $a]$ pyrene, 1,3-butadiene, benzene, formaldehyde, acetaldehyde, acrolein, NNN, NNK, "tar", nicotine, and carbon monoxide. Results showed that CV values highly varied by brands, constituents, and smoking regimes. The constituents which showed the most variable were NNN and NNK, both in the tobacco filler blend and in the smoke.

NNN and NNK yields in tobacco filler blend affected NNN and NNK yields in smoke. In addition, measurement affected benzo $[a]$ pyrene and 1,3-butadine yields in smoke. However, variation of levels of total reducing sugar in tobacco filler blend was not the main factor for the variation for the yields of formaldehyde in smoke. Variation of the amount of charcoal in the filter was not the main factor for the variation of the yields of 1,3-butadiene, benzene, formaldehyde, acetaldehyde, and acrolein constituents. It was shown that factor for variation were highly varied among constituents.

The standard deviation associated with measurement between laboratories was added to the one associated with cigarette manufacturing over ten months and measurement at the JT laboratory in this study. The grand mean of CV values of the yield of formaldehyde showed the highest increase among the constituents. This is due to the fact that formaldehyde showed the highest CV values for reproducibility among the constituents. In order to set realistic and robust confidence intervals for constituents, it is important to take into account variations associated with cigarette manufacturing and those associated with measurement within and between laboratories.

\section{ACKNOWLEDGMENT}

The author wishes to thank Dr. Iwasaki for providing helpful statistical suggestions.

\section{REFERENCES}

1. World Health Organization (WHO) Study Group on Tobacco Product Regulation: The Scientific Basis of Tobacco Product Regulation: WHO Technical Report Series No. 951, 2008. Available at: http://www. who.int/tobacco/global_interaction/tobreg/publicatio ns/tsr_951/en/index.html (accessed November 2017) ISBN 9789241209519

2. Cooperation Centre for Scientific Research Relative to Tobacco (CORESTA): CORESTA Recommended Method No. 58: Determination of Benzo[a]pyrene in Cigarette Mainstream Smoke by GC-MS (July 2014); CORESTA, Paris, France. Available at: https://www. coresta.org/sites/default/files/technical_documents/m ain/CRM_58-update\%28July14\%29.pdf (accessed November 2017)

3. Cooperation Centre for Scientific Research Relative to Tobacco (CORESTA): CORESTA Recommended Method No. 70: Determination of Selected Volatile Organic Compounds in the Mainstream Smoke of Cigarettes - Gas Chromatography-Mass Spectrometry Method (July 2014); CORESTA, Paris, France. Available at: https://www.coresta.org/sites/default/files/tech nical_documents/main/CRM_70-update\%28July 14 \%29.p̄df (accessed November 2017 )

4. Cooperation Centre for Scientific Research Relative to Tobacco (CORESTA): CORESTA Recommended Method No. 74: Determination of Selected Carbonyls in Mainstream Cigarette Smoke by HPLC (July 2014); CORESTA, Paris, France. Available at: https://www. coresta.org/sites/default/files/technical documents $/ \mathrm{m}$ ain/CRM_74-update\%28July14\%29.pdf (accessed November 2017)

5. Cooperation Centre for Scientific Research Relative to Tobacco (CORESTA): CORESTA Recommended Method No. 75: Determination of Tobacco Specific Nitrosamines in Mainstream Cigarette Smoke by LCMS/MS (July 2014); CORESTA, Paris, France. Available at: https://www.coresta.org/sites/default/files/tech nical_documents/main/CRM_75-updateJuly14.pdf (accessed November 2017)

6. Belushkin, M., G. Jaccard, and A. Kondylis: Considerations for Comparative Tobacco Product Assessments Based on Smoke Constituent Yields; Regul. Toxicol. Pharmacol. 73 (2015) 105-113.

DOI: 10.1016/j.yrtph.2015.06.017

7. Eldridge, A., T.R. Betson, M.V. Gama, and K. Mc 
Adam: Variation in Tobacco and Mainstream Smoke Toxicant Yields from Selected Commercial Cigarette Products; Regul. Toxicol. Pharmacol. 71 (2015) 409-427. DOI: 10.1016/j.yrtph.2015.01.006

8. Hanna, S.N., W.T. Morgan, J.M. Rowa, and M.W. Ogden: Contribution of Manufacturing to Variability in Cigarette Constituent Levels; CORESTA Congress, Quebec, Canada, 2014, Smoke Science/Product Technology Groups, ST26. Available at: https://www. coresta.org/abstracts/contribution-manufacturingvariability-cigarette-constituent-levels-27973.html (accessed November 2017)

9. Hyodo, T., K. Minagawa, and A. Mikita: Five-Year Yield Variation in $N$-Nitrosonornicotine and (4Methylnitrosoamino)-1-(3-pyridyl)-1-butanone from the Smoke of Commercial Cigarette Brands on the Japanese Market; Regul. Toxicol. Pharmacol. 73 (2015) 953-959. DOI: 10.1016/j.yrtph.2015.09.019

10. Minagawa, K.: The Long-Term Variability of Selected Smoke Constituents of Commercial Brands in the Japanese Market; CORESTA Congress, Sapporo, Japan, 2012, Smoke Science/Product Technology Groups, SSPT 36. Available at: https://www. coresta.org/abstracts/long-term-variability-selectedsmoke-constituents-commercial-brands-japanesemarket-28864 (accessed November 2017)

11. Morton, M.J. and S.W. Laffoon: Cigarette Smoke Chemistry Market Maps under Massachusetts Department of Public Health Smoking Conditions; Regul. Toxicol. Pharmacol. 51 (2008) 1-30.

DOI: 10.1016/j.yrtph.2008.03.001

12. Rickert, W.S., P.J. Joza, M. Sharifi, J. Wu, and J.H. Lauterbach: Reductions in the Tobacco Specific Nitrosamine (TSNA) Content of Tobaccos Taken from Commercial Canadian Cigarettes and Corresponding Reductions in TSNA Deliveries in Mainstream Smoke from Such Cigarettes; Regul. Toxicol. Pharmacol. 51 (2008) 306-310. DOI: 10.1016/j.yrtph.2008.04.009

13. Oldham, M.J., D.J. DeSoi, L.T. Rimmer, K.A. Wagner, and M.J. Morton: Insights from Analysis for Harmful and Potentially Harmful Constituents (HPHCs) in Tobacco Products; Regul. Toxicol. Pharmacol. 70 (2014) 138-148. DOI: 10.1016/j.yrtph.2014.06.017

14. Piadé, J.J., S. Wajrock, G. Jaccard, and G. Janeke: Formation of Mainstream Cigarette Smoke Constituents Prioritized by the World Health Organization Yield Patterns Observed in Market Surveys, Clustering and Inverse Correlations; Food Chem. Toxicol. 55 (2013) 329-347.

DOI: 10.1016/j.fct.2013.01.016.

15. Morabito, J.A., M.R. Holman, Y.S. Ding, X. Yan, M. Chan, D. Chafin, J. Perez, M.I. Mendez, R.B. Cardenas, and C. Watson: The Use of Charcoal in Modified Cigarette Filters for Mainstream Smoke Carbonyl Reduction; Regul. Toxicol. Pharmacol. 86 (2017) 117-127. DOI: 10.1016/j.yrtph.2017.02.019

16. International Organization for Standardization (ISO): ISO 8243:2013, Cigarettes - Sampling; ISO, Geneva, Switzerland, 2013. Available at: https://www.iso.org/ obp/ui/\#iso:std:iso:8243:ed-5:v1:en (accessed November 2017)

17. International Organization for Standardization (ISO):
ISO/TR 22305:2006, Cigarettes - Measurement of Nicotine-Free Dry Particulate Matter, Nicotine, Water and Carbon Monoxide in Cigarette Smoke - Analysis of Data from Collaborative Studies Reporting Relationships Between Repeatability, Reproducibility and Tolerances; ISO, Geneva, Switzerland, 2006. Available at: https://www.iso.org/obp/ui/\#iso:std:iso:tr:22305:ed1:v1:en (accessed November 2017)

18. International Organization for Standardization (ISO): ISO 3402:1999, Tobacco and Tobacco Products Atmosphere for Conditioning and Testing; ISO, Geneva, Switzerland, 1999. Available at: https:// www.iso.org/standard/28324.html (accessed November 2017)

19. International Organization for Standardization (ISO): ISO 3308:2012, Routine Analytical Cigarette-Smoking Machine - Definitions and Standard Conditions; ISO, Geneva, Switzerland, 2012. Available at: https:// www.iso.org/standard/60404.html (accessed November 2017)

20. International Organization for Standardization (ISO): ISO 4387:2000, Cigarettes - Determination of Total and Nicotine Free Dry Particulate Matter Using a Routine Analytical Smoking Machine; ISO, Geneva, Switzerland, 2008. Available at: https://www.iso.org/ standard/28323.html (accessed November 2017)

21. International Organization for Standardization (ISO): ISO 10315:2013, Cigarettes - Determination of Nicotine in Smoke Condensates - Gas-Chromatographic Method; ISO, Geneva, Switzerland, 2011. Available at: https://www.iso.org/standard/56744.html (accessed November 2017)

22. International Organization for Standardization (ISO): ISO 10362-1:1999, Cigarettes - Determination of Water in Smoke Condensates - Part 1: Gas-Chromatographic Method; ISO, Geneva, Switzerland, 1999. Available at: https://www.iso.org/standard/28322.html (accessed November 2017)

23. International Organization for Standardization (ISO): ISO 8454:2007, Cigarettes - Determination of Carbon Monoxide in the Vapour Phase of Cigarette Smoke NDIR Method; ISO, Geneva, Switzerland, 2007. Available at: https://www.iso.org/standard/41168.html (accessed November 2017)

24. Health Canada: Health Canada Tobacco Reporting Regulation: Official Method T-103. Determination of Benzo[a]pyrene in Mainstream Tobacco Smoke; 1999.

25. Health Canada: Health Canada Tobacco Reporting Regulation: Official Method T-115. Determination of "Tar", Nicotine and Carbon Monoxide in Mainstream Tobacco Smoke; 1999.

26. Cooperation Centre for Scientific Research Relative to Tobacco (CORESTA): CORESTA Recommended Method No. 62: Determination of Nicotine in Tobacco and Tobacco Products by Gas Chromatographic Analysis; CORESTA, Paris, France, 2005. Available at: https://www.coresta.org/sites/default/files/technical documents/main/CRM_62.pdf (accessed November 2017)

27. Wagner, K.A. and I.G. Gillman: The Rapid and Quantitative Analysis of Tobacco Specific Nitrosamines in Whole Tobacco Using LC/MS/MS with Positive Ion 
Electrospray; $55^{\text {th }}$ Tobacco Science Research Conference, 2001, Greensboro, North Carolina, USA, Program Booklet and Abstracts, Vol. 55, Paper No. 57, pp. 53-54.

28. Purkis, S.W., M. Meger, and R. Wuttke: A Review of Current Smoke Constituent Measurement Activities and Aspects of Yield Variability; Regul. Toxicol. Pharmacol. 62 (2012) 202-213. DOI: $10.1016 /$ j.yrtph.2011.10.006

29. Moldoveanu, S.C. and M. Borgerding: Formation of Tobacco Specific Nitrosamines in Mainstream Cigarette Smoke - Part 1, FTC Smoking; Beitr. Tabakforsch. Int. 23 (2008) 19-31.

DOI: $10.2478 / \mathrm{cttr}-2013-0845$

30. Parrish, M.E. and C.N. Harward: Measurement of Formaldehyde in a Single Puff of Cigarette Smoke Using Tunable Diode Laser Infrared Spectroscopy; Appl. Spectroscopy 54 (2000) 1665-1677. DOI: $10.1366 / 0003702001948709$

31. Baggett, M.S. and G.P. Morie: Selective Removal of Semivolatile Components of Cigarette Smoke by Various Filters; Beitr. Tabakforsch. 3 (1975) 150-152. DOI: $10.2478 / \mathrm{cttr}-2013-0372$

32. Williamson, J.T., J.F. Graham, and D.R. Allman: The Modification of Cigarette Smoke by Filter Tips; Beitr. Tabakforsch. 3 (1965) 233-242.
DOI: $10.2478 /$ cttr-2013-0115

33. Counts, M.E., F.S. Hsu, S.W. Laffoon, R.W. Dwyer, and R.H. Cox: Mainstream Smoke Constituent Yields and Predicting Relationships from a Worldwide Market Sample of Cigarette Brands: ISO Smoking Conditions; Regul. Toxicol. Pharmacol. 39 (2004) 111-134.

DOI: 10.1016/j.yrtph.2003.12.005

34. Hyodo, T., Y. Maruta, H. Itaya, A. Mikita, T. Kodera, and M. Meger: Evaluation of Functional Relationships for Predicting Mainstream Smoke Constituent Machine Yields for Conventional Cigarettes from the Japanese Market; Regul. Toxicol. Pharmacol. 48 (2007) 194-224. DOI: 10.1016/j.yrtph.2007.02.003

Corresponding author:

Takatsugu Hyodo

Japan Tobacco INC.

2-2-1 Toranomon Minato-ku,

Tokyo 105-8422

Japan

E-mail: takatsugu.hyodo@jt.com 